\title{
Impacts of Aid for Innovation on Economic Growth in the Sub-Saharan African Countries
}

\author{
Beáta Udvari \\ Ph.D., Assistant Professor, \\ University of Szeged \\ Faculty of Economics and Business Administration \\ Isaac Kwesi Ampah \\ Ph.D. Student, \\ University of Szeged, \\ Faculty of Economics and Business Administration
}

Doi: 10.2478/mjss-2018-0119

\begin{abstract}
For several years, sub-Saharan Africa (SSA) countries continue to struggle with poverty, hunger, epidemics, access to proper sanitation and potable water etc. even though the continent is considered to be endowed with half of the world's natural resources. Low value-added products continue to be the primary export of countries in the continent since it lacks the technical know-how to manage its resources for sustainable growth and development it envisages. This paper examines the effectiveness of aid for innovation in enhancing growth and innovative performance of SSA using the Generalized Method of Moment (GMM) and fixed effect models for the period 2002 to 2015. The empirical results revealed that growth and innovation in the continent could be improved significantly if aid is more advanced to innovation and research. Also, the paper noticed that aid for innovation have more impacts in countries with the lower level of innovation and technological advancement.
\end{abstract}

Keywords: sub-Saharan Africa (SSA); Aid for innovation; Generalized Method of Moment (GMM); Economic Growth; innovation capacities

\section{Introduction}

Half of the world's natural resources such as minerals, large water bodies, rich forest reserves, as well as good climatic conditions are located mostly in Africa, yet the continent is considered the poorest in the world as it lacks the technical know-how to manage its resources for sustainable growth and development it envisages. Global challenges such as poverty, epidemics, access to safe water are still affecting the continent, though these could be handled by adopting appropriate innovation technologies (OECD, 2012). In addition, the countries in Africa are still depending on the export of low value-added products causing problems in their catching-up process. It is not a surprise that only six (6) out of the thirty-nine (39) countries mentioned by the World Bank as Heavily Indebted Poor Countries (HIPCs) are not from Africa. Nevertheless, according to the World Economic Forum (WEF, 2017), economic growth and productivity development are sure to be achieved if there is an improvement in innovation, information and technological competence of these countries.

Interestingly, adoption of appropriate foreign technology, improvement in innovation research and technological advancement has been at the forefront of governance in Africa (Ács \& Szerb, 
2012) yet due to financial constraints, the chances of these countries have been extremely limited. It is in this light that the analysis of the so-called aid for innovation (Montellano \& Vázquez 2015) or knowledge aid (UNCTAD 2007) has already gained importance, as it aims to improve the innovation and technology capacity in developing countries. Although the necessity of aid for innovation is unambiguous (Udvari \& Vas 2017), current studies have not considered the impact of aid devoted to promoting innovation, information and technological abilities, especially in the African context. It is against this background; this study is conducted to investigate how aid for innovation may contribute to economic growth and innovation in Sub-Saharan Africa. In the analysis, both the direct and indirect aid for innovation are taken into consideration to get the overall picture of its impacts on the innovation capacities of Sub-Saharan African countries and on their long-term growth.

Apart from the introduction, the structure of the rest of the paper is as follows. Firstly, we discuss the current literature on aid effectiveness reflecting how the sectoral approach has become more important, and this part gives a basis for our empirical analysis. Then we introduce the concept of and the current findings on aid for innovation. The next part details the method of our econometric model, and finally, we discuss our results on the impacts of aid for innovation.

\section{Aid Effectiveness}

Aid effectiveness is still in the focus of aid literature, and there is still a great debate on the positive and negative impacts of aid on economic growth and development (Kosack, 2003). Some authors could explain the positive relationship between aid and economic growth (e.g. Askarov \& Doucouliagos, 2015b; Feeny \&Vuong, 2017) but some could not prove it (e.g. Burke \& AhmadiEsfahani, 2006; Rajan \& Subramanian, 2008). Doucouliagos and Paldam (2007) summarized the aid effectiveness literature of 40 years and analyzed the results of almost 100 econometric studies. Their conclusion is that aid was not effective in which process the Dutch disease had a significant role. Rajan and Subramanan (2011) also emphasized the role of Dutch disease reflecting that aid may distort the export competitiveness of the recipient country. Therefore, export and aid are competitors (Collier 2008). Arndt, Jones, and Tarp (2015) analyzed the long-term impacts of aid on growth while including more factors (human and physical capital) into their analysis, and their results were positive. Altogether, there are controversial results on aid effectiveness, which raise the need to be more precise when analyzing with either using sectoral dataset or concentrating on only a small number of countries (or both).

Nevertheless, several factors have been identified in the literature to exhibit more influence of aid effectiveness. For instance; political system, Islam (2003) claimed that aid is more effective under strong rather than weak dictatorship, while Kosack (2003) emphasized that aid can positively affect economic growth in democracies, so democratization process needs to be supported in the developing countries. That is why some researchers (e.g. Collier \& Dollar, 2002; or McGillivray et al., 2005) claim that countries with good governance should be the main beneficiaries of international development cooperation. In addition, Dreher, Minasyan, and Nunnenkamp (2015) reechoed that if the political ideology is similar in the recipient and donor countries, aid is more effective than in a recipient country with a completely different ideological environment. Minasyan (2016) also had similar results; Minasyan's results show that the impact of aid on growth is largely influenced by the cultural similarities between the recipient and the donor countries. Development aid is also considered to have more significant indirect impacts on economic growth. For instance, aid to infrastructure development makes the recipient country more attractive to FDI (Donaubauer, Meyer \& Nunnenkamp, 2016), which may also result in economic growth at the end. Askarov and Doucouliagos $(2015 \mathrm{a}, 2015 \mathrm{~b})$ investigated the transitional economies, and they also highlighted that common historical and political heritage results in better spillover effects of aid on economic growth. Concerning tied aid, there is still a debate about its effects (Osei et al. 2009, Wagner 2003), but recently Kim and Kim (2016) showed that tied aid is not necessarily bad for the recipient countries. Bandyopadhyay, Lahiri, and Younas (2015) also found that loans are more effective concerning economic growth than aid is.

It is also criticized that the donors do not harmonize their aid activities, and in the aid 
effectiveness conferences, there are attempts to coordinate their aid activities. Pallas and Ruger (2017) analyzed aid in the health sector, and their results recommended improving the coordination among donor countries. Flogstad and Hagen (2017) have similar results: the coordination between donors and projects (that is, implementing programs instead of projects) is essential to improve aid effectiveness. Lessman and Markwardt (2016) also emphasized that decentralization in the recipient country also influences aid effectiveness. The more decentralized the recipient country is, the less effective aid is, however, the type of decentralization has different impacts: while fiscal decentralization has a negative impact on aid effectiveness, employment decentralization has a positive one, and political decentralization does not have any.

Besides, the impacts of aid are not only analyzed on economic growth but on other issues. For example, Dutta and Williamson (2016) investigated whether aid can contribute to economic freedom in the recipient countries. Their results suggest that aid is more effective in democracies than in autocracies from this point of view. Reinberg (2015) also proved that political liberalization results in more aid to the recipient countries. Askarov and Doucouliagos (2015a) echoed that aid contributes to democratization in transition economies, while Kalyvitis and Vlachaki (2012) showed that aid could not build democracies in developing countries.

Regarding the aid effectiveness literature, the sectoral approach has become more important: the effects of aid provided to a certain sector has been getting more attention (Gopalan \& Rajan 2016). Mainly three sector-specific development assistance appears in the relevant literature: aid to education, aid to health and aid to water supply and sanitation. The impacts of the sector-specific aid are more unambiguous than the total aid. Both Birchler and Michaelowa (2016) and Riddel and Nino-Zarazúa (2016) showed that aid to education sector contributes to primary enrolment. However, the education quality itself cannot be changed. Ndikumana and Pickburn (2017) also investigated the effects of aid provided to water and sanitation sector in Sub-Saharan Africa - their econometric findings suggest that this kind of aid has positive impacts on access to safe water.

Altogether, these controversial results suggest - as Lof, Mekesha, and Tarp (2015) also reflected in their study - that the findings of the empirical analysis strongly depend on the sample country, period and the method the researcher applies. Looking through the aid effectiveness literature, we noticed that the institutional background and good governance should be taken into account when aid effectiveness is analyzed, on the one hand; and we missed any analysis on the impacts of aid for innovation. The sector-specific aid analyses did not cover this field, although innovation and technological development might be crucial for developing countries. In the followings, we will give an attempt to analyze impacts of aid for innovation.

\section{Aid for Innovation}

Although there is technological improvement in the world and markets are globalizing, majority of developing countries in SSA lags behind the technological level of the developed countries'. Considering the total factor productivity as a measure of technological level - as the World Bank (2008) recommends, low-income countries accomplish only 5.2 percent of the US performance, the lower middle-income countries are in the 9.6 percent, while the upper-middle-income countries achieve 23.7 percent. However, technological improvement would be beneficial for developing countries, since - for instance - they could export higher value-added products resulting in more export revenues for the country. At the same time, the strong financial constraints hinder these countries to spend on technological development, so external sources, e.g. official development assistance, may be crucial for them. It seems that there is a pressure on the donor countries because the $9^{\text {th }}$ Sustainable Development Goal (Industry, innovation and infrastructure) also emphasizes innovation development in the developing countries. As the targets of the $9^{\text {th }}$ SDG detail ${ }^{1}$ :

- "Enhance scientific research, upgrade the technological capabilities of industrial sectors in all countries, in particular developing countries, including, by 2030 , encouraging innovation and substantially increasing the number of research and development workers per 1

\footnotetext{
${ }^{1}$ http://www.un.org/sustainabledevelopment/infrastructure-industrialization/
} 
million people and public and private research and development spending."

- "Support domestic technology development, research and innovation in developing countries, including by ensuring a conducive policy environment for, inter alia, industrial diversification and value addition to commodities."

- "Significantly increase access to information and communications technology and strive to provide universal and affordable access to the internet in the least developed countries by 2020."

Knowledge-based aiding started in the middle of the 1990s, and numerous donors (e.g. the United Kingdom, Canada or Japan) supported this (King, 2000; Molla, 2014). However, instead of direct knowledge aid - because of lack of knowledge of the local environment - building research capacities was rather more beneficial (Molla 2014). As a result, aid for innovation has become more important. Udvari and Vas (2017), in a related study, analyzed the aid for innovation allocation involving 115 developing countries. Based on their findings, the following conclusion can be made concerning the trends of aid for innovation:

- Only $1 \%$ of the total bilateral aid is directed to innovation sectors; however, in Asia, Africa, and Oceania, this value is much above the average of the developed countries. Oceania value was the best with the average of $6-8 \%$.

- The amount of aid for innovation in average significantly decreased from the period of 2005-2007 to 2012-2014. However, this drop was different across the regions: in SubSaharan Africa, only 1 percentage point decrease was experienced, while in Central Asia the proportion of aid for innovation in the total bilateral decreased to its one-tenth.

- Significant volatility was clearly seen to be a characteristic of aid for innovation allocated.

- Analyzing the 20 largest recipient countries of aid for innovation, the authors concluded that there is no concentration in the case of this type of aid: the TOP20 countries receive only one-third of the total aid for innovation.

- Although China is one of the largest emerging donors nowadays (Kilama 2016), China belongs to the TOP20 countries receiving the most aid for innovation.

Although this analysis showed that aid for innovation amounts only a relatively small proportion of the total bilateral aid, it impacts on economic growth was found to be positive, and the result suggested stronger positive impacts in countries with lower innovation capacities as also concluded by Montellano and Vázquez (2015). This raises the question of whether aid for innovation may have any impact on economic growth and innovation in Sub-Saharan African countries.

\section{Methodology}

The study uses secondary data drawn from the OECD's aid database, the World Bank (World Development Indicators, International Financial Statistics), and the Polity IV database for the Polity 2 data series. Concerning the aid for innovation, the OECD CRS database was used, however, it does not contain the precise data for aid for innovation data, therefore, in calculating the value of aid for innovation, the study follows Naudé (2011) and UNCTAD (2007) recommendations, who also suggested that aid for innovation, can be categorized into two main groups:

- Direct aid for innovation which represents aid spent on research and technological development (also called aid for research and technological development)

- Indirect aid for innovation is aid which supports the sectors that are necessary to the success of direct aid for innovation (e.g. higher education, training) (called as an aid for improving advanced and specific innovation skills).

In examining the impact of aid for innovation, this study uses both the (direct and indirect) aid for innovation because both can contribute to economic growth. The tabulation for the Direct and Indirect Aid for innovation considered in this study is presented in Table 1. The dataset consists of time-series running from 2002 to 2015, and it covers fifty-two (52) Sub-Saharan African countries. 
Table I. Direct and indirect aid for innovation

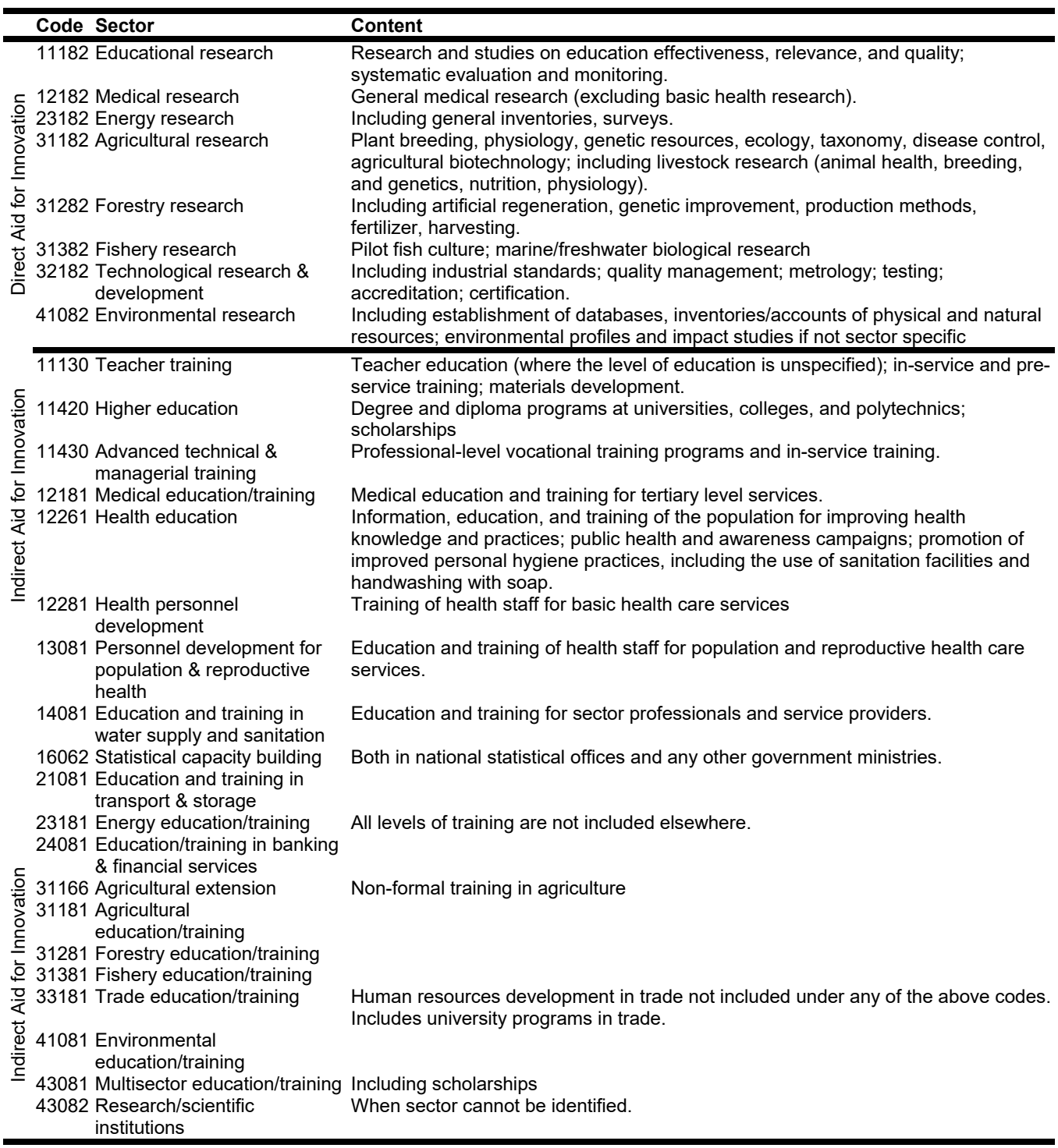

Source: Naudé (2011), UNCTAD (2007) and OECD (2016)

\subsection{Model Specification and Estimation}

Since the main aim of this paper is to investigate the impacts of aid for innovation on innovation capacity of SSA countries and their growth, this study shall estimate two empirical models. The first is an inquiry of the impact of aid for innovation on innovation performance of SSA countries. This is achieved by estimating the equation below;

$I N N O_{i t}=\delta I N N O_{i t-1}+\beta X_{i t}+\beta Z_{i t}+u_{i}+\varepsilon_{i t}$

Where INNO represent innovation capacities of SSA, $X$ captures Aid for innovation-related 
factors, $Z$ is a vector of other control variables of INNO other than aid for innovation. The parameters $\delta$ and $\beta$ are the coefficients of $X$ and $Z$ to be estimated. ${ }^{\varepsilon_{i t}}$ accounts for the stochastic error term and ${ }^{u_{i}}$ denotes the unobserved country-specific time-invariant effect. ${ }^{i}$ stand for a particular country, and $t$ is time. Following the work of Barro (1991) and Montellano \& Vázquez (2015), this study adopts human capital development and institutional quality as aid for innovation related variables. In addition, macroeconomic instability (inflation), political stability, trade openness and financial development is considered as the other control variables in the model. Equation 1 can, therefore, be specified again as

$$
\begin{aligned}
& I N N O_{i t}=\alpha_{1}+\beta_{1} I N N O_{i t-1}+\beta_{2} A D_{i t}+\beta_{3} A I_{i t}+\beta_{4} A H C_{i t}+\beta_{5} A I N S T_{i t}+\beta_{6} P O L I T Y_{i t}+\beta_{7} F D_{i t}+\beta_{8} T O_{i t}+\beta_{9} I N F_{i t}+ \\
& u_{i}+\varepsilon_{i t}
\end{aligned}
$$

Where INNO represent innovation capacities of SSA, AD is the Direct Aid for Innovation, and Al is the Indirect Aid for Innovation. AHC is also the interaction between aid for innovation and Human Capital, and AINST is the interaction between aid for innovation and institutional quality. POLITY represents political stability, BD represents Budget Deficit, and FD is financial development.

The second empirical model is an investigation of the impacts of aid for innovation on the growth of SSA countries. This is done by estimating equation 3 as

$$
G D P_{i t}=\delta Y_{i t-1}+\beta X_{i t}+\beta Z_{i t}+\sigma_{i}+\psi_{i t}
$$

Where GDP represent annual GDP per capita growth rate, $X$ captures aid for innovationrelated factors, and $Z$ captures the growth-related variables indicated in equation 3.

Equation 3 can be extended and represented as

$$
\begin{aligned}
& G D P_{i t}=\alpha_{1}+\beta_{1} Y_{i t-1}+\beta_{2} I N N O_{i t}+\beta_{3} A D_{i t}+\beta_{4} A I_{i t}+\beta_{5} A I N N O_{i t}+\beta_{6} A H C_{i t}+\beta_{7} \ln A I N S T_{i t}+\beta_{8} P O L I T Y_{i t}+\beta_{9} F D_{i t}+ \\
& \beta_{10} T O_{i t}+\beta_{11} I N F_{i t}+\sigma_{i}+\psi_{i t}
\end{aligned}
$$

Where AINNO is the interaction between aid for innovation and innovation capacity, $\sigma$ is the

\begin{tabular}{|c|c|c|}
\hline Variable & Definition and Measurement & Source \\
\hline GDP & $\begin{array}{l}\text { Annual growth rate of the GDP per capita. It is measured as the annual percentage growth } \\
\text { rate of GDP per capita based on constant } 2010 \text { U.S. dollars }\end{array}$ & WDI database \\
\hline INNO & $\begin{array}{l}\text { Innovation capacity of countries. Measured by the number of scientific and technical journal } \\
\text { papers published. The OECD's Manual }(2002) \text { suggested this indicator for measuring } \\
\text { innovation capacities in developing countries. }\end{array}$ & WDI database \\
\hline$A D$ & $\begin{array}{l}\text { Direct Aid for Innovation. It entails aid provided to promote technological, scientific and } \\
\text { innovative progress in developing countries. It is made up of aid provided to the various } \\
\text { sectors; education, health, water, and sanitation, etc. }\end{array}$ & OECD database \\
\hline Al & $\begin{array}{l}\text { Indirect Aid for Innovation and it consist of aid provided for training and capacity building for } \\
\text { the recipient countries. }\end{array}$ & OECD database \\
\hline AINNO & $\begin{array}{l}\text { It is the interaction between aid for innovation and innovation capacity of the recipient } \\
\text { country. }\end{array}$ & WDI database \\
\hline $\mathrm{AHC}$ & $\begin{array}{l}\text { It is the interaction between aid for innovation and human capital development. The human } \\
\text { capital development is measured by the percentage of the population aged } 25 \text { and over who } \\
\text { have completed secondary school. }\end{array}$ & $\begin{array}{l}\text { Barro and Lee } \\
\text { study (2000). }\end{array}$ \\
\hline AINST & $\begin{array}{l}\text { It is the interaction between aid for innovation and institutional quality. Institutional quality in } \\
\text { this study takes the average of i) voice and accountability, ii) political stability and absence } \\
\text { of violence, iii) government effectiveness, iv) regulatory quality, v) the rule of law and vi) } \\
\text { control of corruption. }\end{array}$ & $\begin{array}{l}\text { Kaufmann et al. } \\
(2014)\end{array}$ \\
\hline POLITY & $\begin{array}{l}\text { Political Stability is measured by the country's elections competitiveness and openness, the } \\
\text { nature of political involvement in general, and the degree of checks on administrative } \\
\text { authority. The estimate gives the country's score on the aggregate indicator, in units of a } \\
\text { standard normal distribution, i.e. ranging from }-10 \text { to }+10 \text {. }\end{array}$ & $\begin{array}{l}\text { Polity } 2 \text { data series } \\
\text { from Polity IV } \\
\text { database under }\end{array}$ \\
\hline FD & This is financial development, and it is measured by $M 2$ as a percentage of GDP & WDI database \\
\hline TO & $\begin{array}{l}\text { Trade openness is defined in the study as the sum of imports and exports of goods and } \\
\text { services as a share of gross domestic product }\end{array}$ & WDI database \\
\hline INF & Inflation rate is also measured as the growth rate of the $\mathrm{CPI}$ index & WDI database \\
\hline
\end{tabular}
unobserved country-specific time-invariant effect and $\psi$ is the error term. All other variables are defined as before. Table 2 presents the variable description and measurement, as well as their source.

Table 2: Variables in the model: Definitions and Sources

Source: Compiled by the Authors 
The econometric models presented in this paper favours the use of dynamic panel data modelling. Specifically, this paper adopts the system GMM model by Arellano and Bover (1995) for its estimation. The choice of the GMM procedure for this paper is best because it resolves the Dynamic panel bias problem resulting from the endogeneity associated with the variables. In addition, the system GMM works to remove the serial correlation and heteroscedasticity associated with the times series analysis. Nevertheless, this paper compares the result to Fixed effect estimation. The fixed effect estimation enables this paper to account for the individual country effects that may affect the association between aid and growth.

\section{Discussion of the Estimated Results}

From the model specification, two estimated results are described here. The first set contains the results of the impact of aid for innovation on innovation capacity of SSA countries and the second contains the results for the impact of aid for innovation on the growth of these countries. These results are presented in Tables 3 and 4 respectively. Table 3 presents the results for the innovation capacity, and Table 4 contains the results for the impact on growth.

Table 3: The estimated result of the impact of aid for innovation on innovation capacities of SSA countries

\begin{tabular}{lcccccc}
\hline & \multicolumn{3}{c}{ GMM model } & \multicolumn{3}{c}{ Fixed Effect Model } \\
\hline Variables & Coeff. & Std. Err & Prob. & Coeff. & Std. Err & Prob. \\
INNO(-1) & 0.6721 & 0.0462 & 0.0000 & & & \\
AD & 0.3441 & 0.1588 & 0.0300 & 0.7280 & 0.0950 & 0.0000 \\
AI & 0.1720 & 0.1572 & 0.0620 & 0.2373 & 0.1108 & 0.0330 \\
AHC & 0.0819 & 0.0856 & 0.3390 & 0.3483 & 0.0490 & 0.0000 \\
AINST & 0.0143 & 0.0097 & 0.1420 & -0.0068 & 0.0085 & 0.4260 \\
POLITY & -0.0085 & 0.0075 & 0.2610 & -0.0192 & 0.0052 & 0.0000 \\
FD & 0.0044 & 0.0017 & 0.0100 & 0.0052 & 0.0010 & 0.0000 \\
TO & -0.0030 & 0.0008 & 0.0000 & -0.0005 & 0.0040 & 0.2170 \\
INF & 0.0112 & 0.0029 & 0.0000 & 0.0009 & 0.0022 & 0.6740 \\
CON & -1.3456 & 0.5424 & 0.0130 & -2.3292 & 0.3219 & 0.0000 \\
\hline
\end{tabular}

Source: Computed using Stata 13

The results in Table 3 support the view that aid for innovation has positive impacts on the innovation capacities of SSA countries. This is clearly indicated by the coefficients of both the direct and direct aid as they all portray positive and statistically significant in both the GMM and the fixed effect models. The positive and statistical significance of both direct and indirect aid for innovation on the innovation capacities of SSA countries thus indicate that improvement in the allocation of aid to innovation in SSA countries will enable them to generate more innovative ideas to boost their trade, technology and marketing strategies to enrich their competitiveness at the global scale. In addition, the result serves as a signal to governments in SSA to allocate more resource to research and development, at least the 1 percent of their GDP as agreed upon at African Union summit in 2007, to enhance their innovation. In addition, the result in Table 3 confirms that political insatiability kills innovative investment of people. This is evident in the coefficient of political stability, as it is negative and statistically significant in both the GMM and the fixed effect model. This result concurs with the result of Escribano, Guasch and Pena (2010) that poor political environment in SSA has decreases innovative and industrial development in the region. Again, the results confirm that promoting financial development among countries in SSA will promote innovation among them since financial development postulated positive and significant impact on innovation. The negative and statistically significant impact of trade openness also signifies that countries in the region have not developed their trade sector much well; therefore, openness in trade rather kills their innovation, and they become uncompetitive in the international market. 
Table 4: The estimated result of the impact of aid for innovation on the growth of SSA countries

\begin{tabular}{lcccccc}
\hline & \multicolumn{3}{c}{ GMM model } & \multicolumn{3}{c}{ Fixed Effect Model } \\
\cline { 2 - 7 } Variables & Coeff. & Std. Err & Prob & Coeff. & Std. Err & Prob \\
\hline GDP(-1) & 0.5757 & 0.1491 & 0.000 & & & \\
INNO & 0.1478 & 0.0516 & 0.004 & 0.2213 & 0.0328 & 0.0000 \\
AD & 0.0865 & 0.0428 & 0.043 & 0.0846 & 0.0228 & 0.0000 \\
Al & 0.0435 & 0.0223 & 0.051 & 0.0241 & 0.0254 & 0.3440 \\
AINNO & -0.1376 & 0.0478 & 0.004 & -0.1200 & 0.0344 & 0.0010 \\
AHC & 0.0323 & 0.2560 & 0.099 & 0.0508 & 0.0117 & 0.0000 \\
AINST & 0.0068 & 0.0041 & 0.095 & 0.0095 & 0.0019 & 0.0000 \\
POLITY & 0.0023 & 0.0044 & 0.604 & 0.0014 & 0.0012 & 0.2480 \\
FD & 0.0020 & 0.0009 & 0.017 & 0.0008 & 0.0002 & 0.0000 \\
TO & 0.0000 & 0.0002 & 0.798 & 0.0000 & 0.0001 & 0.6570 \\
INF & -0.0016 & 0.0009 & 0.067 & -0.0013 & 0.0005 & 0.0110 \\
CONS & 0.2240 & 0.0280 & 0.000 & 2.4576 & 0.0769 & 0.0000 \\
\hline Wald chi2(13) & \multicolumn{7}{c}{468.4} & 0.0000 & & & \\
AR(1) & -0.11568 & 0.9079 & & & \\
AR(2) & -0.32952 & 0.7418 & & & \\
Sangan Test & 37.47495 & 0.984 & & & \\
\hline
\end{tabular}

Source: Computed using Stata 13

The results in Table 4 shows that annual GDP growth of the previous period has a positive and statistically significant influence on current GDP growth. While the innovation capacity of countries in the sub-region and both direct and indirect aid for innovation, the interaction between aid for innovation and Human Capital $(\mathrm{AHC})$ and aid for innovation and institutional quality have a positive and statistically significant effect on GDP per capita growth in both the GMM and fixed effect model. The interaction between aid for innovation and innovation capacity of countries rather had a negative impact growth. On the growth-related variables, political stability, financial development and trade openness, all have the expected positive sign though trade openness and political stability are not statistically significant. This means that political stability and trade openness do not have a statistically significant impact on GDP per capita growth. Inflation also had the expected negative sign and is significant too.

Overall, the study confirms the results reported by previous studies that aid for innovation has a positive impact on economic growth. In both the GMM and the fixed effect model, the coefficient of both the direct and indirect aid for innovation had a significant positive sign though it may seem a limited impact. According to Mantellano and Vasquez (2015), this is, in fact, noteworthy given that the contribution of aid for innovation to the sample countries' GDP is exiguous. This result lays the foundation for more aid for innovation program in the sample countries. Next, the study shows clearly in those areas that can be influenced enormously by adequate aid for innovation programs. These crucial areas for the aid for innovation agenda are human capital and institutional quality since these factors obviously have a direct consequences on GDP per capita growth. Identifying these factors is crucial for pursuing aid for innovation programs, as improving them may promote further growth and innovation in the recipient countries.

In relation to the growth determinant variables, the study found two of them to be statistically significant. The positive and significant effect of the financial development is in conformity with the projections of the endogenous growth theorists that financial deepening has a positive relationship with economic growth. Again, this result concurs with the findings of Quartey and Prah (2008) for Sub-Saharan Africa. As anticipated, inflation, which is used to capture macroeconomic instability is appropriately signed and is statically significant. This means that if SSA is streamlining their investment regulatory framework, implementing policies that will promote macroeconomic stability, will help achieve a higher level of economic growth (Asiedu, 2006). 
Furthermore, the interaction term between aid for innovation and innovation of countries is negative and statistically significant. This result is captivating, as it demonstrates that the impact of aid for innovation is higher in countries with lower innovation and technological advancement (such as Mantellano and Vasquez (2015) concluded in their study), which signifies higher allocation of resources to these countries. Overall, the implication is that if aid for innovation is significant and effective particularly in low-income countries, then, it could serve as a suitable medium for closing the innovation gap between the higher and the low-income countries, especially if it is directed to the appropriate nations. In this way, the study of Udvari and Vas (2017) and Montellano, \& Vázquez (2015) supports this view that if least innovative developing countries receive proportionally more aid for innovation than most innovative countries, then, innovation and technological advancement in these countries will be improved.

\section{Conclusion and Policy Implication}

In the past few years, the sectoral impacts of aid have been in perspective since the aid literature portrayed total aid studies to have produced controversial results on economic growth, and therefore aid effectiveness as far as total aid is concerned is deeply criticized. Nevertheless, the sectoral impacts are more persuasive confirming its significance as beneficial. Since technological development may lead to economic catch-up in developing countries, the aid for innovation as a type of aid has gained more importance. Though it is a relatively small portion of total bilateral aid, it can have a significant impact on economic growth and development. Employing GMM and fixed effect model for 52 SSA countries, this study focused on the question of how aid for innovation contributes to economic growth and innovation capacities of countries in Sub-Saharan African. Our empirical analysis revealed this condition, and we observed that aid for innovation has more impacts in countries with the lower level of innovation capacity. This justifies the need for a unique and higher aid allocation system for these countries to bridge the innovation gap between the rich and the poor countries.

\section{Acknowledgement}

Supported by the ÚNKP-16-4 New National Excellence Program of the Ministry of Human Capacities.

\section{References}

Ács, Z. J., \& Szerb, L. (2012). Global entrepreneurship and development index 2012. Edward Elgar Publishing.

Arellano, M., \& Bover, O. (1995). Another look at the instrumental variable estimation of error-components models. Journal of Econometrics, 68(1), 29-51.

Arndt, C., Jones, S., \& Tarp, F. (2015). Assessing foreign aid's long-run contribution to growth and development. World Development, 69, 6-18.

Asiedu, E. (2006). Foreign direct investment in Africa: The role of natural resources, market size, government policy, institutions and political instability. The World Economy, 29(1), 63-77.

Askarov, Z., \& Doucouliagos, H. (2015a). Spatial aid spillovers during transition. European Journal of Political Economy, 40, 79-95.

Askarov, Z., \& Doucouliagos, H. (2015b). Development aid and growth in transition countries. World Development, 66, 383-399.

Bandyopadhyay, S., Lahiri, S., \& Younas, J. (2015). Financing growth through foreign aid and private foreign loans: Nonlinearities and complementarities. Journal of International Money and Finance, 56, 75-96.

Barro, R. J. (1991). Economic growth in a cross-section of countries. The quarterly journal of economics, 106(2), 407-443.

Birchler, K., \& Michaelowa, K. (2016). Making aid work for education in developing countries: An analysis of aid effectiveness for primary education coverage and quality. International Journal of Educational Development, 48, 37-52.

Burke, P. J., \& Ahmadi-Esfahani, F. Z. (2006). Aid and growth: A study of South East Asia. Journal of Asian Economics, 17(2), 350-362.

Collier, P., \& Dollar, D. (2002). Aid allocation and poverty reduction. European economic review, 46(8), 1475-1500.

Donaubauer, J., Meyer, B., \& Nunnenkamp, P. (2016). Aid, infrastructure, and FDI: Assessing the transmission channel with a new index of infrastructure. World Development, 78, 230-245. 
Dreher, A., Minasyan, A., \& Nunnenkamp, P. (2015). Government ideology in donor and recipient countries: Does ideological proximity matter for the effectiveness of aid?. European Economic Review, 79, 80-92.

Dutta, N., \& Williamson, C. R. (2016). Aiding economic freedom: Exploring the role of political institutions. European Journal of Political Economy, 45, 24-38.

Escribano, A., Guasch, J. L., \& Pena, J. (2010). Assessing the impact of infrastructure quality on firm productivity in Africa: cross-country comparisons based on investment climate surveys from 1999 to 2005. Retrieved from https://e-archivo.uc3m.es/bitstream/handle/10016/6101/ we098649pdf?sequence=1.

Feeny, S., \& Vuong, V. (2017). Explaining aid project and program success: Findings from Asian Development Bank Interventions. World Development, 90, 329-343.

Fløgstad, C., \& Hagen, R. J. (2017). Aid dispersion: Measurement in principle and practice. World Development, 97, 232-250.

Islam, M. N. (2003). Political regimes and the effects of foreign aid on economic growth. The Journal of Developing Areas, 37(1), 35-53.

Kalyvitis, S., \& Vlachaki, I. (2012). When does more aid imply less democracy? An empirical examination. European Journal of Political Economy, 28(1), 132-146.

Kilama, E. G. (2016). The influence of China and emerging donors aid allocation: A recipient perspective. China Economic Review, 38, 76-91.

Kim, S. K., \& Kim, Y. H. (2016). Is tied aid bad for the recipient countries?. Economic Modelling, 53, $289-301$.

Kosack, S. (2003). Effective aid: How democracy allows development aid to improve the quality of life. World development, 31(1), 1-22.

Lessmann, C., \& Markwardt, G. (2016). Aid, Growth, and Devolution: Considering Aid Modality and Different Types of Decentralization. World Development, 84, 118-130.

Lof, M., Mekasha, T. J., \& Tarp, F. (2015). Aid and income: Another time-series perspective. World Development, 69, 19-30.

Lukovics, M., \& Fisher, E. (2017). Socio-technical integration research in an Eastern European setting: Distinct features, challenges and opportunities. Society and Economy, 39(4), 501-528.

McGillivray, M., Feeny, S., Hermes, N., \& Lensink, R. (2005). Controversies over the impact of development aid: it works; it doesn't; it can, but that depends.... Journal of International Development, 18(7), 1031-1050.

Minasyan, A. (2016). Aid, Politics, Culture, and Growth(Doctoral dissertation, Lower Saxony State and University Library Göttingen). Retrieved from https://d-nb.info/108095449X/34.

Molla, T. (2014). Knowledge aid as instrument of regulation: World Bank's non-lending higher education support for Ethiopia. Comparative Education, 50(2), 229-248.

Montellano, A. Q., \& Vázquez, S. T. (2015). Aid \& innovation: a boost to the effectiveness of aid?" Revista International de Cooperación y Desarrollo 2(1), 5-36.

Naudé, W. (2011). Foreign Aid for Innovation: The Missing Ingredient in Private Sector Development?' (No. 2011/35).

Ndikumana, L., \& Pickbourn, L. (2017). The impact of foreign aid allocation on access to social services in subSaharan Africa: the case of water and sanitation. World Development, 90, 104-114.

OECD. (2012). Innovation for Development. The Directorate for Science, Technology, and Industry, OECD, Paris.

OECD. (2016). The List of CRS Purpose Codes. Organization for Economic Cooperation and Development, Paris.

Osei, R., Morrissey, O., \& Lloyd, T. (2004). The nature of aid and trade relationships. The European Journal of Development Research, 16(2), 354-374.

Pallas, S. W., \& Ruger, J. P. (2017). Effects of donor proliferation in development aid for health on health program performance: A conceptual framework. Social Science \& Medicine, 175, 177-186.

Rajan, R. G., \& Subramanian, A. (2008). Aid and growth: What does the cross-country evidence really show?. The Review of economics and Statistics, 90(4), 643-665.

Reinsberg, B. (2015). Foreign aid responses to political liberalization. World Development, 75, 46-61.

Riddell, A., \& Niño-Zarazúa, M. (2016). The effectiveness of foreign aid to education: What can be learned?. International Journal of Educational Development, 48, 23-36.

Sumida, S. (2017). Donor's motivation of the educational aid. International Journal of Educational Development, 55, 17-29.

Udvari, B., \& Vas, Z. (2017). Nemzetközi fejlesztési segélyezés az innováció területén. International development assistance on innovation, Külgazdaság, 7(8), 74-101

UNCTAD (2007): The Least Developed Countries Report 2007. Geneva and New York: United Nations on Conference and Trade.

Wagner, D. (2003). Aid and trade-an empirical study. Journal of the Japanese and international economies, 17(2), 153-173.

WEF (2017): Global Competitiveness Report 2016-2017. World Economic Forum, Geneva.

World Bank (2008). Global Economic Prospects. Technology Diffusion in the Developing World. The World Bank, Washington. 